\title{
Діагностично-лікувальний алгоритм при післяопераційних тромбозах системи нижньої порожнистої вени
}

\author{
S. YA. KOSTIV, I. K. VENHER, O. I. KOSTIV \\ SHEI "Ternopil State Medical University by I. Ya. Horbashevsky"
}

\section{ALGORITHM OF THE DIAGNOSTIC AND TREATMENT AT POSTOPERATIVE THROMBOSIS OF THE INFERIOR VENA CAVA SYSTEM}

\begin{abstract}
У роботі обгрунтовано застосування діагностично-лікувального алгоритму при хірургічному втручанні у пацієнтів із високим ризиком розвитку венозних тромбоемболічних ускладнень, що дало можливість знизити частоту розвитку післяопераційного венозного тромбозу в басейні нижньої порожнистої вени у хворих із плановою хірургічною патологією у 1,95 раза, а у хворих з ургентною хірургічною патологією - у 2,62 раза.
\end{abstract}

The paper substantiates the use of diagnostic and treatment algorithm for the surgical intervention in patients with high risk of venous thromboembolic events, making it possible to reduce the incidence of postoperative venous thrombosis in the inferior vena cava system in patients with planned surgical pathology in 1.95 times, and in patients with urgent surgical pathology - in 2.62 times.

Постановка проблеми і аналіз останніх досліджень тапублікацій. Венозний тромбоемболізм становить на сьогодні одну з найбільш актуальних, але, на жаль, все ж не до кінця вирішених проблем не тільки хірургії, але й медицини на сучасному етапі [1]. Більше 30 \% випадків тромбозу глибоких вен та тромбоемболії легеневої артерії безпосередньо пов’язані із загальнохірургічними операційними втручаннями. Після операцій з приводу ортопедичної патології частота розвитку вказаних ускладнень складає близько 50 \% [2].

Сучасний підхід до застосування тромбопрофілактики грунтується на виділенні груп ризику розвитку венозних тромбоемболічних ускладнень із застосуванням різних схем антикоагулянтних препаратів. Призначення в клінічній практиці галузевих протоколів тромбопрофілактики знизило кількість післяопераційних тромботичних ускладнень, але все ж частота розвитку венозного тромбозу утримується на високому рівні [3]. Післяопераційний тромбоз у системі нижньої порожнистої вени $\epsilon$ джерелом розвитку фатальної емболії легеневої артерії, з частотою 0,2-0,9 \% [4].

Мета роботи: для зниження частоти розвитку післяопераційних венозних тромбоемболічних ускладнень запропонувати алгоритм, що включає ранню ультрасонографічну діагностику венозного тромботичного процесу в басейні нижньої порожнистої вени з наступним вибором лікувальної тактики.
Матеріали і методи. У роботу включено 624 пацієнти, які перебували на стаціонарному лікуванні у хірургічних відділеннях КЗ ТОР “Тернопільська університетська лікарня” з 2009 до 2013 р.

Серед хворих, яких включено в дослідження, 472 (75,6 \%) пацієнти оперовано з приводу планової хірургічної патології, а 152 (24,4 \%) хворим виконано хірургічне втручання з приводу ургентної патології.

У післяопераційному періоді розвиток тромботичного процесу в системі нижньої порожнистої вени було встановлено у 134 (21,47 \%) пацієнтів. Варикотромбофлебіт діагностовано у 27 (4,33 \%) хворих, а тромботичний процес у системі глибоких вен нижньої порожнистої вени - у 107 (17,15 \%) пацієнтів.

За часом діагностування тромботичного процесу в післяопераційному періоді пацієнтів розподілили таким чином: у 72 (53,7 \%) хворих тромботичний процес виявляли на 3-4-ту добу післяопераційного періоду, у 41 (30,6 \%) пацієнта - на 5-6-ту добу та у 19 (14,2 \%) випадках - на 7-му та пізніші доби післяопераційного періоду.

На етапі планової підготовки пацієнтів до операційного лікування у 2 (1,5 \%) хворих було діагностовано ілеофеморальний тромбоз із флотацією верхівки тромбу на рівні інфраренального сегмента НПВ. У зв'язку з цим операційне лікування основного захворювання було поєднано із ліквідацією ілеофеморального тромбозу з флотуючою верхівкою. 
При інструментальному дослідженні емболонебезпечний флотуючий тромб у системі глибоких вен басейну нижньої порожнистої вени встановлено у 35 (32,71 \%) спостереженнях, емболонебезпечний оклюзійний венозний тромб - у 8 (7,45 \%) хворих, оклюзійний венозний тромбоз - у 64 (59,81 \%) випадках.

Слід відмітити, що емболонебезпечні форми тромботичного процесу у венозній системі виявлялися на час появи клінічних проявів не пізніше 5-ї доби післяопераційного періоду, що спонукало проводити ультразвукове дослідження стану венозної системи. Пізня діагностика тромботичного процесу створює загрозу розвитку ТЕЛА.

При встановленні тромботичного процесу 3 флотуючою верхівкою та емболонебезпечного оклюзійного тромбу з метою попередження загро- зи розвитку ТЕЛА проводили операційне лікування за ургентними показаннями.

У зв'язку з тим, що діагностика тромботичного процесу в басейні НПВ проводиться на момент клінічних проявів, що може призвести до розвитку ускладнення ТЕЛА, запропоновано здійснювати ультрасонографічний моніторинг стану венозного русла у пацієнтів із високим ризиком (хворі з об'ємними захворюваннями органів таза, онкопатологією черевної порожнини, ознаками неспецифічної дисплазії сполучної тканини) на етапі підготовки до операційного втручання та в ранньому післяопераційному періоді.

Запропонований діагностично-лікувальний алгоритм (схема 1) застосовано у 152 пацієнтів у період 2013-2014 pp.

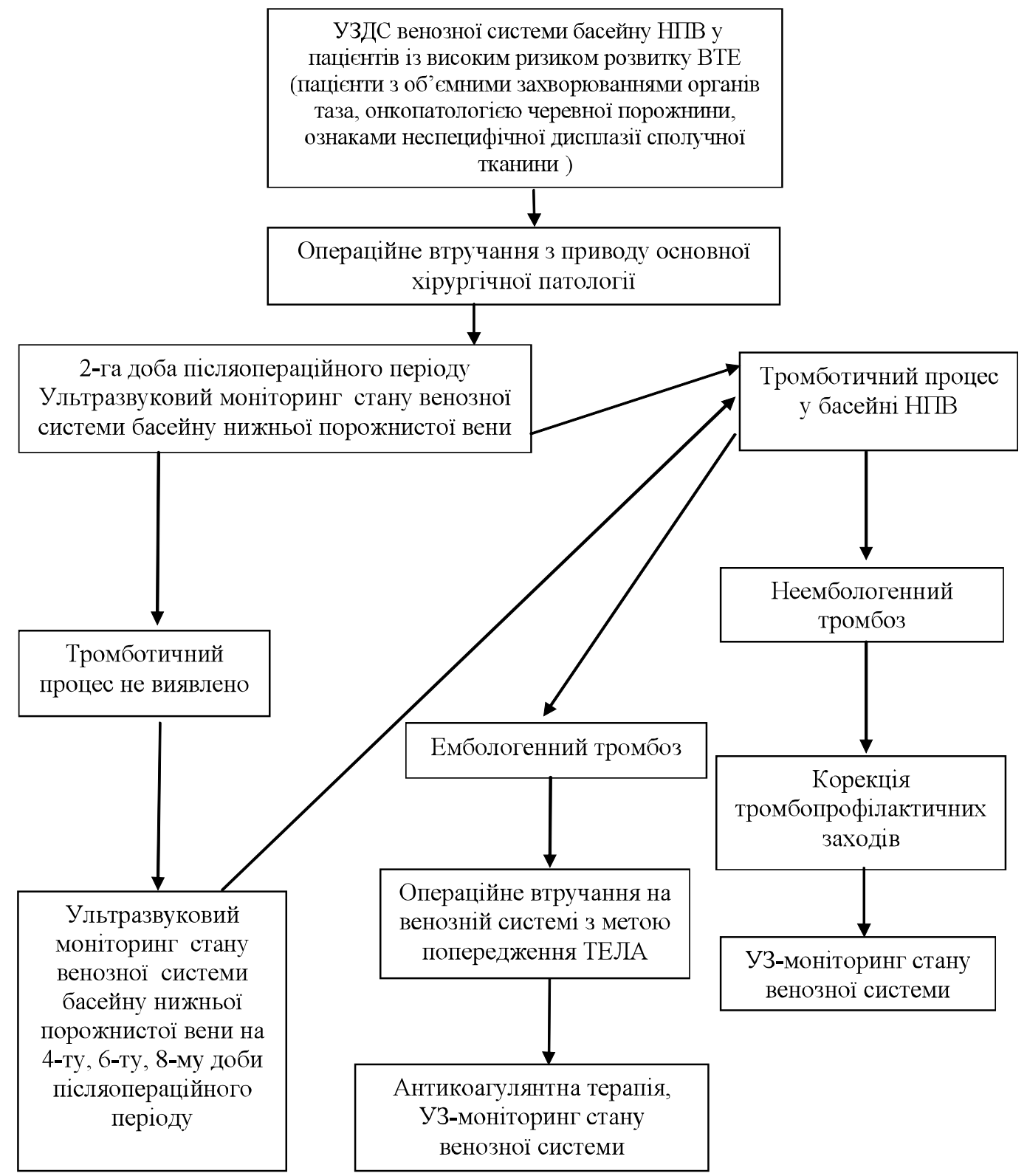

Схема 1. Діагностично-лікувальний алгоритм. 
Результати досліджень та їх обговорення. У 152 пацієнтів застосовано запропонований діагностично-лікувальний алгоритм, серед яких 113 (74,3 \%) склали хворі з плановою хірургічною патологією, а 39 (25,6 \%) осіб - пацієнти з ургентною хірургічною патологією. Вказана група пацієнтів за своїм складом, характером патології, об'ємом операційних втручань, супутньою патологією відповідала хворим, які лікувались в КЗ ТОР “Тернопільська університетська лікарня” 2009 до 2013 р.

У цій групі пацієнтів було застосовано розроблений спосіб тромбопрофілактики, що включає, не порушуючи схему введення низькомолекулярних гепаринів, застосування нефракціонованого гепарину безпосередньо після операційного втручання внутрішньовенно за допомогою інфузомату в першу годину післяопераційного періоду в дозі 5000 ОД у хворих із високим рівнем хірургічного стресу та 2500 ОД у хворих з помірним та низьким ступенем хірургічного стресу; із продовженням введення препарату в післяопераційному періоді до 4-5-ї доби в дозі 2500 ОД 3 рази на добу [5].

Розвиток післяопераційного тромбозу в басейні нижньої порожнистої вени діагностовано у 16 (10,53 \%) спостереженнях. Венозний тромбоз реє-

\section{СПИСОК ЛІТЕРАТУРИ}

1. Российские клинические рекомендации по диагностике, лечению и профилактике венозных тромбоэмболических осложнений. - М. : Изд-во Медиа Сфера. - 2010. - 56 с.

2. Bratzler D. W. Underase of venousthromboembolism prophilaxis for general surgery patients: physician practicesin the community hospital setting / D. W. Bratzler // Arch. Intern. Med. - 1998. - Vol. 158. - P. 1909-1912.

3. Low-molecular weight heparin (enoxaparin) as prophylaxis against venous thromboembolism after total hip replacement / стрували на кінець 2-ї та на початку 3-ї доби післяопераційного періоду. Слід відмітити, що тромботичний процес локалізувався на рівні дистальних відділів венозної системи нижніх кінцівок і в більшості у пацієнтів після ортопедичних операційних втручань.

Тромботичний процес у басейні підшкірних вен діагностовано у 4 (25,00 \%) хворих, а тромбоз у системі глибоких вен нижньої порожнистої вени встановлено у 12 (75,00 \%) пацієнтів. Встановлений післяопераційний венозний тромбоз у вказаної групи пацієнтів не вимагав проведення операційного лікування для попередження ТЕЛА.

Висновок. Застосування запропонованого діагностично-лікувального алгоритму дозволило знизити частоту післяопераційних венозних тромбозів у системі НПВ у хворих із плановою хірургічною патологією у 1,95 раза, а у хворих з ургентною хірургічною патологією - у 2,62 раза.

Перспективи подальших досліджень. Запропонований діагностично-лікувальний алгоритм вимагає удосконалення в підходах до тромбопрофілакти в пацієнтів з ургентною хірургічною патологією групи високого ризику розвитку ВТЕ.

D. Bergqvist, G. Benoni, O. Bjorgell [et al.] / N. Engl J. Med. 1996. - Vol. 335. - P. 696-700.

4. Geerts W. H. Prevention of venous thromboembolism: The Seventh ACCP Conference on Antithrombotic and Thrombolytic Therapy / W. H. Geerts // Chest. - 2004. - Vol. 126. - P. 338-400. 5. Венгер I. К. Обгрунтування способу тромбопрофілактики у пацієнтів із високим ризиком розвитку венозних тромбоемболічних ускладнень / I. К. Венгер, С. Я. Костів // Шпитальна хірургія. - 2015. - № 1. - С. 32-33. 